\title{
Are characteristics of sharia supervisory boards able to improve the performance of islamic banking?
}

\author{
Ratna Fitriana, ${ }^{1}$ Agung Yulianto, ${ }^{2}$ \\ Badingatus Solikhah ${ }^{3}$ \\ 1,2,3Universitas Negeri Semarang, Indonesia \\ email: ratnafitriana9@gmail.com
}

\begin{abstract}
Purpose - The purpose of this study was to examine the effect of characteristics of Sharia Supervisory Board (DPS) such as DPS scientific background, dual positions of DPS, and the number of supervision days on the performance of Islamic banking. This paper also analyze profit sharing financing as an intervening variabl

Method - The population of this study is Islamic Banks in Indonesia in 2012-2017 are 13 sharia bank. The selection of samples in this study using purposive sampling method and selected 8 banks. The data was analyzed using multiple linear regression analysis, path analysis, and sobel test.

Result-The results showed that the number of DPS supervision days has a positive effect on the Sharia financial performance, multiple positions of DPS have a positive effect on profit sharing financing. The profit sharing financing is not able to mediate the relationship of the characteristics of the Sharia Supervisory Board to the Sharia financial performance.

Implication - Islamic Commercial Banks in Indonesia suggest to improve the financial performance in accordance with sharia principles.

Originality - This research is the first study that used intervening variable profit sharing financing.
\end{abstract}

Keywords: sharia supervisory board; sharia financial performance; profit sharing financing 
Ratna Fitriana, Agung Yulianto, Badingatus Solikhah

\section{Introduction}

Health and financial level performance is defined as the ability of a bank to carry out banking operations normally and the ability to fulfill all ob-

JIAFR | 2 ligations properly and its implementation in accordance with predetermined banking regulations (Bukair \& Rahman, 2015; Hameed et. al., 2004). The performance of Islamic banks needs to be assessed so that investors are aware of the development of funds that have been invested. Banking performance in general can be measured using financial ratios such as liquidity ratios, profitability ratios and others. However, the assessment of Islamic banks performance is far more complex and it is not only seen from the level of profitability of the bank but also compliance with syariah principles (Yulianto \& Solikhah, 2016).

Ghifari, et al. (2015) argued that conventional convulsions have many weaknesses in practice, including: (1) it is still difficult to distinguish characteristics between Islamic banks and conventional banks (Zaman \& Movassaghi, 2002). This difference is due to the differences in views on Islamic finance which affect their function as intermediaries and the need to adapt to local circumstances and regulations (Hawary et al., 2004; Ghifari et al., 2015); (2) many research results state that it is certainly not the same as conventional banks in measuring the performance of Islamic banks because they differ in their core functions and operational characteristics; and (3) the basic purpose of the existence of Islamic banking itself has not been dealt with seriously so that in measuring the performance of Islamic banking, it still uses conventional measuring instruments that only focus on financial measurement. Even though there is a need to develop measurement of banking performance in accordance with syariah principles.

Based on the website of (http://www.infobanknews.com), Infobank's 2014 Syariah Commercial Bank rating indicated a decline in performance in a number of banks compared to the previous year. Out of a total of 12 BUS, only 4 BUS have managed to maintain their performance and achieve excellent titles, namely Paninbank Syariah, BNI Syariah, Maybank Syariah 
Indonesia, and BCA Syariah. However, the number reached 9 BUS last year. The Infobank Research Bureau also noted that there was one bank whose title has increased, namely Bank Syariah Bukopin, from good enough to good. The correction of the performance of Islamic banks, both Syariah Commercial Banks (BUS) and Syariah Business Units (UUS) has the potential to slow down the pace of Islamic banking. The movement of Islamic banks must again stumble the economic slowdown. Nevertheless, when compared to the assets of the Islamic finance industry, Islamic banking still dominates. Based on BirI data as of May 2015, Islamic banking assets towards the total assets of the Indonesian Islamic finance industry reached 83.07\%.

Empirically, the research on the financial performance of Islamic banks has been carried out by some researchers, but the results have not been consistent. As the research conducted by Hasanah (2015) with the title of compliance with syariah principles and Islamic Corporate Governance on financial health in Islamic commercial banks showed that the implementation of the duties and responsibilities of the Syariah Supervisory Board had a significant positive effect on BUS financial security in Indonesia. While Arifni's (2015) research entitled the influence of Islamic good corporate governance on profit sharing financing through syariah compliance indicated that the implementation of the duties and responsibilities of the Syariah Supervisory Board did not affect syariah compliance, but the implementation of the duties and responsibilities of the Syariah Supervisory Board had a positive effect on the profit sharing financing through syariah compliance. Rama and Novela (2015) in their research entitled Syariah Governance and the quality of syariah banking governance found that Syariah Governance practices had a significant effect on the quality of Islamic Bank Corporate Governance, where Syariah Governance was represented in the form of DPS membership, DPS education qualifications, and frequency of DPS meetings. The more number of DPS members, the education level of DPS with doctoral qualifications and the presence of DPS meetings increased, the more the quality of Islamic bank corporate governance improved. 
Of the phenomenon and the previous researches before, researchers then intends to reexamine the influence of the characteristics of the Syariah Supervisory Board as DPS scientific members, DPS dual position, and the number of days the DPS monitoring the financial performance of Islamic banks through profit sharing financing as intervening variable. This study adds profit sharing financing as an intervening variable which is based on previous research conducted by Suhendar and Tanuatmodjo (2014) which showed that the profit sharing financing affected the profitability proxied through the Return on Assets (ROA) at Islamic Banks in Indonesia.

\section{Literature Review}

Syariah Enterprise Theory (SET) is used as a theory to explain the financial performance of Syariah Commercial Banks. As explained by Triyuwono (2007) SET explained that real assets belong to God and were only entrusted to humans. These resources are a mandate that will be held accountable, so that stakeholders must utilize and manage their property properly according to Allah's orders.

Stewardhsip theory is a theory to test a situation where the management of a company service is not motivated by individual goals but rather is aimed at their primary outcome goals for the benefit of the organization (Davis, et al., 1997). This theory is used to explain the relationship between DPS scientific background variables, dual DPS positions, number of days DPS supervision as the independent variable, while profit sharing financing as the intervening variable. As the Syariah Supervisory Board carries out its duties and responsibilities properly, the distribution of profit sharing at Islamic commercial banks will increase.

Islamic Corporate Governance theory in an Islamic perspective links all concepts and behaviors in business governance with things that are transcendental and immanent. Sudaryati and Eskadewi (2012) stated that supporters of the Islamic Corporate Governance approach emphasize Corporate Governance must be value oriented and develop fairness and justice by paying attention to all company stakeholders. The relevance of the 
theory of Islamic Corporate Governance to financial performance of Islamic banks is the fulfillment of the syariah principles in the execution of its business operations are achieved through good governance of Islamic banks. It is represented in the mechanism of corporate governance in the form of compliance with the principle of adherence of syariah and the structure has an organ called the DPS which reflected in the level of effectiveness and efficiency of DPS. The implementation of the duties and responsibilities of the DPS as a supervisor and advisor requires that DPS members must be independent and have competencies that support their professionalism.

\section{Hypothesis Development}

Supervising Islamic banking financial institutions is the mandate of DPS. Therefore, DPS members must be people who are experts in their fields. In accordance with the applicable provisions that DPS members are people who have integral scientific qualifications, namely having a scientific background in the field of fiqh muammalah and Islamic finance economics (Usamah, 2010) .

Rama and Novela (2015) proved that the scientific background of DPS had a significant effect on the quality of Islamic bank corporate governance. In line with the theory of Islamic Corporate Governance that links all concepts and behaviors in business governance with things that are transcendental and immanent. DPS whose a scientific background in the field of syariah muammalat and knowledge in banking or finance in general can improve the financial performance of Islamic banks.

$H_{1}$ : DPS scientific background has a positive effect on the financial performance of Syariah Commercial Banks

In carrying out its duties, DPS is limited by the number of positions or dual positions by the DSN with a maximum of four positions so that DPS can work more focused and professional. The fewer concurrent positions as DPS, the more focused and professional it will be able to work so as to improve the financial performance of Syariah Commercial Banks. 
Rifai \& Asrori (2017) showed that dual positions of DPS had a significant effect on the performance of Islamic finance. In line with the theory of Islamic Corporate Governance that links all concepts and behaviors in business governance with things that are transcendental and immanent. DPS whose less dual positions can improve the financial performance of Syariah Commercial Banks in general. Usamah (2010) also indicated that dual positions influenced the performance of syariah -based profit sharing financing significantly.

\section{$\mathrm{H}_{2}$ : Dual positions in DPS have a negative effect on the financial performance of Syariah Commercial Banks}

DPS which functions as the supervisor and advisor must be guided by syariah principles. The supervision carried out by DPS is reflected in the level of good supervision of the operational implementation of Islamic banks as evidenced by the presence of the DPS or the number of DPS supervision days. The number of DPS supervision days allows efforts to improve compliance with Islamic banks in their operations in accordance with syariah principles.

DPS supervision described by Usamah (2010) that the number of days of supervision proved to have an effect on syariah h-compliant financing based on profit sharing because it was reflected in the probability of significance for the number of days of oversight at $0.029 p$ there was a level of $5 \%(\alpha)(p=$ $0.029 ; p>0.05$ ), thus the higher the amount of time of supervision, the higher the level of Islamic compliance.

In line with the theory of Islamic Corporate Governance that links all concepts and behaviors in business governance with things that are transcendental and immanent. The more the number, the better the DPS supervision of the financial performance of Islamic banks.

$H_{3}$ : The number of DPS supervision days has a positive effect on the financial performance of Syariah Commercial Banks 
The Syariah Supervisory Board (DPS) has the duty to provide supervision and advice regarding the management of Islamic banks, so that with the presence of DPS, Islamic banks must carry out activities for the distribution of revenue sharing in accordance with syariah principles. In Islamic institutional supervision, the ability of the Syariah Supervisory Board is very important in providing advice for the implementation of Islamic banking performance based on syariah principles. The ability of the DPS is represented through its scientific background.

Stewardship theory explains that the management of a company service is not motivated by individual goals but rather is aimed at their primary outcome goals for the benefit of the organization (Davis, et al., 1997). In syariah banking operations, DPS has a very important role to oversee all syariah banking business activities in accordance with syariah principles including the profit sharing financing. The Syariah Supervisory Board with its scientific background can be trusted to act as well as possible for the interests of the public and stakeholders so that this is where trust in Islamic banking can be grown. Increasing public trust in Islamic banking can increase profit sharing financing because this financing is related to syariah principles. Hence, the better the DPS scientific background, the better the results-based financing.

The result of the research by Asrori (2014) suggested that Islamic Corporate Governance through the great implementation of the tasks and responsibilities of Syariah Supervisory Board will affect the profit sharingfinancingrate in the Islamic banking.

\section{$\mathrm{H}_{4}$ : Scientific background of Syariah Supervisory Board has a positive effect on theprofit sharing financing.}

In carrying out its duties, Syariah Supervisory Board limited by the number of positions or dual positions by the DSN with a maximum of four positions so that DPS can more focused and professional in working, the fewer concurrent positions as DPS, the more focused and professional in working so thatit can increase the profit sharing financing- 
based. Usamah (2010) conducted a study regarding the dual position of DPS activities, that multiple positions proved to have an effect on syariahcompliant of the profit sharing financing.

JIAFR | 8 In line with the stewardship theory that management as a waiter is not motivated by the goals of individuals but rather aimed at their main objectives to interests of the organization (Davis etal,,1997), so that The Syariah Supervisory Board will carry out its duties and responsibilities in accordance with syariah principles. In Islamic banking operations, the fewer the number of dual positions of the Syariah Supervisory Board, the higher the profit sharing financing will be.

\section{$H_{5:}$ Double positions in Syariah Supervisory Board have a negative effect} on the of profit sharing financing.

Syariah Supervisory Board has a function of supervision and advisory must be guided by syariah principles. The supervision carried out by Syariah Supervisory Board is reflected in the level of good supervision of the operational implementation of Islamic banks as the evidenced by the presence of the Syariah Supervisory Board or the number of Syariah Supervisory Board supervision days. The number of Syariah Supervisory Board supervision days allows efforts to improve compliance with Islamic banks in their operations in accordance with syariah principles.

Syariah Supervisory Board supervision described by Usamah (2010) in his research illustrates that the number of days of supervision proved to have an effect on syariah compliant financing based on profit sharing, thus the higher the amount of supervision time, the higher the level of $h$ compliance. In line with the stewardship theory that management as a servant is not motivated by individual goals but rather is aimed at their primary outcome goals for the benefit of the organization (Davis et al., 1997), so that The Syariah Supervisory Board will carry out its duties and responsibilities in accordance with syariah principles.

$H_{6}$ : The number of days the Syariah Supervisory Board supervision has a positive effect on of profit sharing financing. 
Profit sharing financing is one of the products provided by Islamic banks to customers, profit sharing financing influences the financial performance of Islamic commercial banks, namely the size of the company's profits. The high and low value of financing for the results will affect the returns generated and will affect the financial performance of Islamic banks because with the profit sharing fund channeled to customers, the bank expects to get a return and profit sharing ratio for the financing provided to customers who then divide the results into bank profits. The higher the profit-based financing, the better the financial performance of syariah commercial banks.

Suhendar and Tanuatmodjo (2014) in his research shows that profit sharing financing has an effect on profitability that is proxied through Return on Assets (ROA) in Islamic Commercial Banks in Indonesia.

\section{$H_{7}:$ Profit sharing financing has a positive effect on the financial performance of Syariah commercial banks}

The Syariah Supervisory Board with its scientific background can be trusted to act as well as possible for the interests of the public and stakeholders so that this is where trust in Islamic banking can be grown. Increasing public trust in Islamic banking can increase profit sharing financing because this financing is most in accordance with syariah principles and the increase in the financial performance of syariah commercial banks. A good Syariah Supervisory Board scientific background will improve the financial performance of syariah commercial banks through profit sharing financing.

Rifai \& Asrori (2017) research shows that VAF calculation of Islamic reporting suitability mediation effects on Syariah Supervisory Board scientific background relationships with Islamic financial performance is 1.927 or $192.7 \%$ and shows that the suitability of Islamic reporting is a full mediation of the relationship between the scientific background of the Syariah Supervisory Board and the financial performance of syariah commercial banks. 
Ratna Fitriana, Agung Yulianto, Badingatus Solikhah
$H_{8}$ : Syariah Supervisory Board scientific background has a positive effect on the financial performance of Islamic Commercial Banks through financing results

JIAFR | 10

The form of dual positions of Syariah Supervisory Board stated in a GCG report as the implications of Islamic Corporate Governance. Syariah Supervisory Board questioned by holding concurrent positions because his work will not be focused. Syariah Supervisory Board that has multiple positions will not be maximal in its performance assessing the fulfillment of syariah principles that have an impact on decreasing the performance of Islamic banks in terms of syariah compliance. This will affect the market share because the performance of Islamic banks is considered to be less than optimal. And a Syariah Supervisory Board that does not hold concurrent positions will be able to work more focused and professional so that it can increase financing for profit sharing.

In line with the theory of Islamic Corporate Governance that links all concepts and behaviors in business governance with things that are transcendental and immanent. The fewer the number of dual positions of the Syariah Supervisory Board, the higher the financial performance of syariah commercial banks through increasing financing for profit sharing.

$H_{9}$ : Double positions in Syariah Supervisory Board have negative influence on the financial performance of Islamic Commercial Banks through financing for profit sharing.

The supervision carried out by Syariah Supervisory Boardis reflected in the level of good supervision of the operational implementation of Islamic banks as evidenced by the presence of the Syariah Supervisory Board the number of Syariah Supervisory Board supervision days. The number of Syariah Supervisory Boardsupervision days allows efforts to improve compliance with Islamic banks in their operations in accordance with syariah principles. 
The Sharia Supervisory Board supervision described by Usamah (2010) in his research illustrates that the number of days of supervision proved to have an effect on syariah-based financing of profitsharing, thus the higher the amount of time supervision, the higher the profit sharing based financing and the increasing financial performance of Islamic banks. In line with Rifai \& Asrori research (2017) which shows that the presence of Syariah Supervisory Board meetings has a significant effect on the performance of Islamic finance.

$H_{10}$ : The number of Syariah Supervisory Board supervision days has a positive effect on the financial performance of Islamic Commercial Banks through profit sharing financing

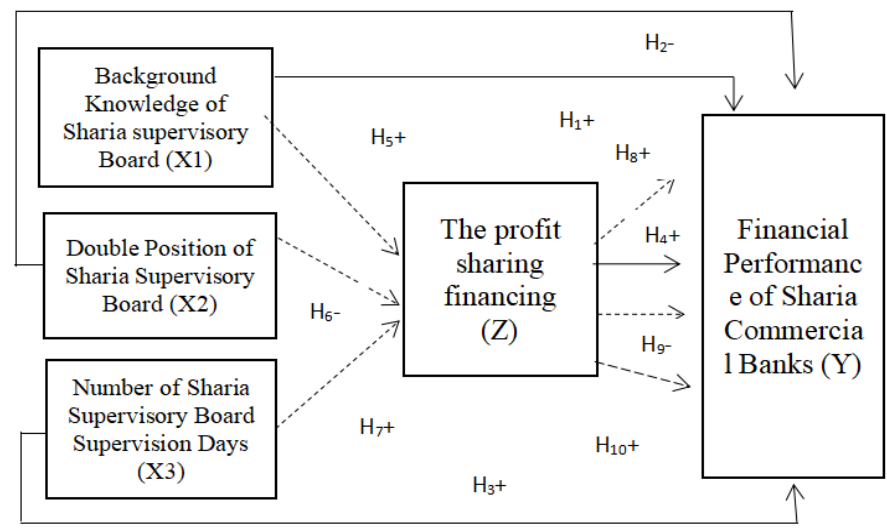

Figure 1. Theoretical Framework

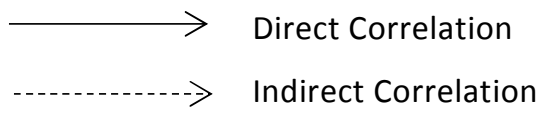

Journal of Islamic Accounting and Finance Research - Vol. 1 No. 1 (2019) 
Ratna Fitriana, Agung Yulianto, Badingatus Solikhah

\section{Research Methods}

This is a quantitative research, the data used is secondary data taken from annual reports of Islamic Banks and reports on the implementation Good JIAFR | 12 Corporate Governance (GCG) sharia commercial bank in Indonesian 20122017. The population of the study was 13 sharia commercial bank in Indonesia. The method of selecting the of samples using purposive technique sampling with the number of samples obtained as many as 8 BUS.

The variables of this study were the financial performance of syariah commercial banks as the dependent variable, and the independent were the scientific background of the Syariah Supervisory Board, dual positions of Syariah Supervisory Board and the number of Sharia Supervisory Board supervision days, as well as the profit sharing financing as an intervening variable. Following are the operational definitions of each variable.

Table 1. Operational Research Variables

\begin{tabular}{|c|c|c|}
\hline Variable & Definition & Measurement \\
\hline $\begin{array}{l}\text { Financial } \\
\text { Performance of } \\
\text { Syariah } \\
\text { Commercial } \\
\text { Banks }\end{array}$ & $\begin{array}{l}\text { Performance is used } \\
\text { to assess the extent } \\
\text { to which Islamic } \\
\text { banks operate } \\
\text { according to syariah } \\
\text { principles }\end{array}$ & $\begin{array}{l}\frac{(A I x A I I)+(A I x R P I)+(A I x A Z)}{3} \\
\text { Hameed, et al. }(2004)\end{array}$ \\
\hline $\begin{array}{l}\text { Scientific } \\
\text { Background of } \\
\text { Syariah } \\
\text { Supervisory } \\
\text { Board }\end{array}$ & $\begin{array}{l}\text { Knowledge } \\
\text { possessed by a } \\
\text { Syariah Supervisory } \\
\text { Board in carrying out } \\
\text { the duties and } \\
\text { responsibilities of } \\
\text { supervision and } \\
\text { advisors }\end{array}$ & $\begin{array}{l}\frac{\text { LBKDPS } 1+L B K D P S 2+\cdots+\text { LBKDPSn }}{\text { Total of DPS Members }} \\
\text { Usamah (2010), Rifai \& Asrori (2017) }\end{array}$ \\
\hline $\begin{array}{l}\text { Double Position } \\
\text { of Syariah } \\
\text { Supervisory } \\
\text { Board }\end{array}$ & $\begin{array}{l}\text { Syariah Supervisory } \\
\text { Board members who } \\
\text { are currently } \\
\text { occupying a } \\
\text { structural position in } \\
\text { the management of }\end{array}$ & $\begin{array}{c}\text { DPS Duplicate Pasitions }= \\
\Sigma_{\text {RJDPS } 1+\text { RJDPS } 2+\text { RJDPS } 3+\cdots+\text { RJDPSn }} \\
\text { Usamah (2010), Rifai \& Asrori (2017) }\end{array}$ \\
\hline
\end{tabular}




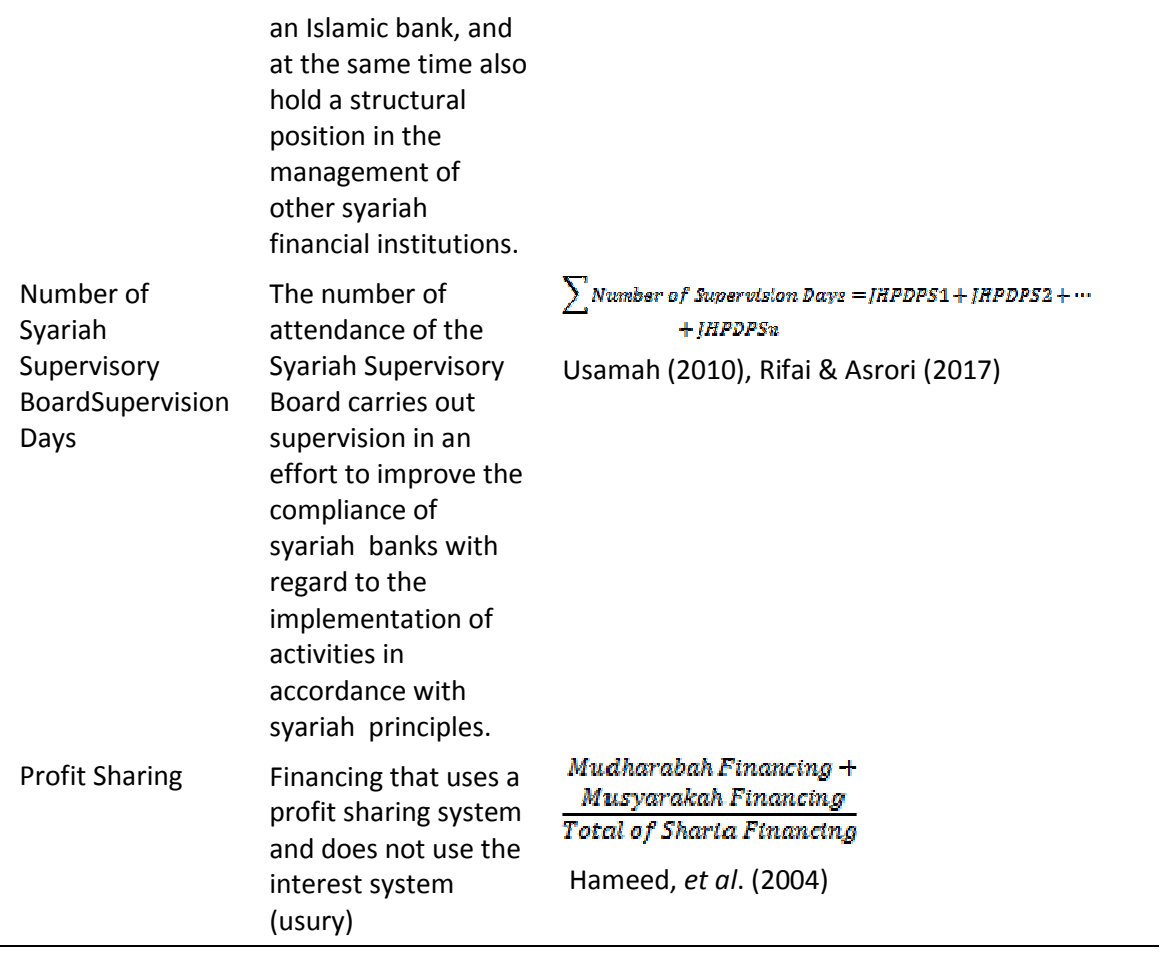

The data collection techniques in this study was documentation technique by collecting secondary data from the annual reports of sharia commercial bank and reports on the implementation of Good Corporate Governance (GCG) in 2012-2017. Data analysis technique used was descriptive analysis and inferential analysis. In testing the Hypothesis it was used a multiple linear regression analysis to examine the direct effect of the independent variables, and using path analysis and Sobeltest to test the indirect effect of through intervening variables.

\section{Results and Discussion}

Descriptive statistical results of this research were the study variable data describing the minimum value, maximum value, average value (mean) and standard deviation. The results of the descriptive statistics test for each variable can be seen in the table 2 . 
Ratna Fitriana, Agung Yulianto, Badingatus Solikhah

The classical assumptions test used in this studywere the normality test, multi-coloniarity, auto-correlation and hetero skedassitasti test. The test results used the Kolmogorov Smirnovshow that normal distribution regression model designated showed asymptonic significance values greater than 0.05 is equal to 0.291 .

The second classical assumption was multicoloniarity done by looking at the value of Tolerance and Variance Inflation Factor (VIF) where the result is that all independent variables showed the absence of Tolerance value less than 0.10 and not more than 10. The thirdclassical assumption was autocorrelation using Durbin-Watson test (DW) which showed that there were no autocorrelation designated by DW value whis is in the middle value $\mathrm{dl}$ and 4 - du, it was $1.378<1.966<4$ to 1.721 . The fourth classical assumption was heteroskedastisitas test using graphic scatterplotand white pointingtest that showed that there were not heteroskedastisitas in regression model which showed in graphicscatterplot. It can be seen that the dots spread randomly either above or below the point 0 at $Y$ axis in the white test results which showing that $\mathrm{C} 2$ value was smaller than $\mathrm{C} 2$ table.

Table 2. Descriptive Statistics Test Results

\begin{tabular}{lccccc}
\hline \multicolumn{1}{c}{ Variable } & N & Min & Max & Mean & Std. Dev \\
\hline $\begin{array}{l}\text { Scientific Background of } \\
\text { Syariah Supervisory Board }\end{array}$ & 48 & 2.00 & 3.00 & 2,4896 &, 29505 \\
$\begin{array}{l}\text { Double Position of Syariah } \\
\text { Supervisory Board }\end{array}$ & 48 & 3 & 12 & 7,06 & 2,462 \\
$\begin{array}{l}\text { Number of Syariah } \\
\begin{array}{l}\text { Supervisory Board } \\
\text { Supervision Days }\end{array}\end{array}$ & 48 & 14 & 43 & 29,23 & 6,429 \\
$\begin{array}{l}\text { Profit Sharing } \\
\begin{array}{l}\text { Financial Performance of } \\
\text { Syariah Commercial Banks }\end{array}\end{array}$ & 48 &, 01 &, 91 &, 3871 &, 23743 \\
\hline
\end{tabular}


Are characteristics of sharia supervisory boards able to ...

Table 3. Hypothesis Test Results

\begin{tabular}{|c|c|c|c|c|c|c|}
\hline No. & & Hypothesis & B & Sig. & 回 & Results \\
\hline 1 & $\mathrm{H}_{1}$ & $\begin{array}{l}\text { DPS scientific background has a } \\
\text { positive effect on the financial } \\
\text { performance of Islamic } \\
\text { commercial banks }\end{array}$ & $-0,022$ & 0,410 & 0.05 & Rejected \\
\hline 2 & $\mathrm{H}_{2}$ & $\begin{array}{l}\text { Dual DPS positions have } \\
\text { anegative effect on the financial } \\
\text { performance of syariah } \\
\text { commercial banks }\end{array}$ & $-0,001$ & 0,777 & 0.05 & Rejected \\
\hline 3 & $\mathrm{H}_{3}$ & $\begin{array}{l}\text { The number of DPS supervision } \\
\text { days has a positive effect on the } \\
\text { financial performance of } \\
\text { syariah commercial banks }\end{array}$ & 0,003 & 0.003 & 0.05 & Accepted \\
\hline 4 & $\mathrm{H}_{4}$ & $\begin{array}{l}\text { The scientific background of } \\
\text { DPS has a positive effect } \\
\text { on financing for profit sharing }\end{array}$ & $-0,204$ & 0,089 & 0.05 & Rejected \\
\hline 5 & $\mathrm{H}_{5}$ & $\begin{array}{l}\text { Double positions in DPS have } \\
\text { a negative effect on financing } \\
\text { for profit sharing }\end{array}$ & $-0,040$ & 0.007 & 0.05 & Accepted \\
\hline 6 & $\mathrm{H}_{6}$ & $\begin{array}{l}\text { The number of DPS supervision } \\
\text { days has a positive effect } \\
\text { on revenue sharing }\end{array}$ & 0,006 & 0,255 & 0.05 & Rejected \\
\hline 7 & $\mathrm{H}_{7}$ & $\begin{array}{l}\text { Profit sharing has a positive } \\
\text { effect on the financial } \\
\text { performance of syariah } \\
\text { commercial banks }\end{array}$ & $-0,026$ & 0,429 & 0.05 & Rejected \\
\hline 8 & $\mathrm{H}_{8}$ & $\begin{array}{l}\text { The scientific background of the } \\
\text { DPS has a positive effect on the } \\
\text { financial performance of } \\
\text { syariah commercial banks } \\
\text { through profit sharing financing }\end{array}$ & $-0,017$ & $\begin{array}{c}0,663< \\
1.68\end{array}$ & & Rejected \\
\hline 9 & $\mathrm{H}_{9}$ & $\begin{array}{l}\text { Dual positions in DPS have } \\
\text { a negative effect on the } \\
\text { financial performance of } \\
\text { syariah commercial banks } \\
\text { through profit sharing financing }\end{array}$ & 0,00004 & $\begin{array}{c}0,693< \\
1.68\end{array}$ & & Rejected \\
\hline 10 & $\mathrm{H}_{10}$ & $\begin{array}{l}\text { The number of DPS supervision } \\
\text { days has a positive effect on the } \\
\text { financial performance of } \\
\text { syariah commercial banks } \\
\text { through profit sharing financing }\end{array}$ & 0,0028 & $\begin{array}{c}0,542< \\
1.68\end{array}$ & & Rejected \\
\hline
\end{tabular}

Journal of Islamic Accounting and Finance Research - Vol. 1 No. 1 (2019) 


\section{The Effect of DPS Scientific Background Financial Performance Against Syariah Banks}

DPS scientific background does not affect the financial performance of JIAFR | 16 syariah commercial banks. The results of this study are not in accordance with the Islamic Corporate Governance theory that links all concepts and behavior in business governance with things that are transcendental and immanent.DPS that have an educational background in sharia economics/banking and finance economics can generally improve the financial performance of syariah commercial banks. In accordance with the research of Usamah (2010) which concluded that the scientific background variable did not significantly influence syariah-based financing of profit sharing.

\section{Positions influence DPS Financial Performance Against Syariah banks}

The dual position of DPS does not affect the financial performance of syariah commercial banks. These results are not in accordance with the theory of Islamic Corporate Governance that links all concepts and behavior in business governance with things that are transcendental and immanent. DPS that has fewer positions generally can improve the financial performance of syariah commercial banks.

The reason why the second hypothesis is rejected is because most members of the DPS who have double position did not exceed four agencies. The average dual position of DPS in descriptive statistics is 7.06 for syariah commercial banks consisting of 2 to 3 DPS. This figure shows that each DPS member only holds a position as a DPS only in a number of Islamic financial institutions, not exceeding the stipulation limit, which is a maximum of 4 agencies. That is double the post of DPS in monitoring sharia commercial bank is relatively small, so it does not influence the financial performance of sharia banks. 


\section{The Effect of Number of Days Supervision towards DPS Financial of Syariah general Banks}

Number of days affects DPS supervision positively to the financial performance of syariah banks. In line with the theory of Islamic Corporate Governance that links all concepts and behaviors in business governance with things that are transcendental and immanent. The more days the DPS supervision is getting, the better the financial performance of syariah commercial banks. The results of this study are in accordance with the study of Usamah (2010) which concluded that the variable number of days of DPS supervision significantly influence the syariah-based financing of profitsharing financing at the level of $5 \%(\alpha)(p=0.029 ; p<0.05)$. This shows that the more days the supervision is carried out, the better.

The facts obtained from Syariah banking show that DPS which conducts supervision with a relatively high number of supervision days in a year, the financial performance of Islamic Commercial Banks is also high. on the contrary if the DPS supervises with a relatively low number of supervision days in a year, the financial performance of Islamic Commercial Banks decreases. Therefore, the higher the number of DPS supervision days, the higher the performance of the financial performance of Syariah Commercial Banks.

\section{DPS Scientific Background Influence of Profit Sharing}

DPS scientific background does notaffect the financing of profit sharing. This is not in accordance with the stewardship theory that management as a servant is not motivated by individual goals but rather is aimed at their primary outcome goals for the benefit of the organization (Davis et al. , 1997), so that The Syariah Supervisory Board will carry out its duties and responsibilities in accordance with syariah principles. In the syariah bank, DPS has an important role in monitoring all syariah bank activities so that it is suitable with the syariah principles including profit sharing. 
Of the 20 DPS from 8 Sharia Commercial Banks in Indonesia, 13 DPS are graduated of economics/sharia economics/banking and finance or about 65\%. 6 DPS people are graduated of postgraduates economics/sharia economics/banking and finance or around 30\%. And only 1 DPS is graduated in economics/sharia economics/banking and finance or around $5 \%$.

In accordance with the study of Usamah (2010) which concluded that the scientific background variable did not significantly affect syariah-based financing of profit-sharing financing at the level of $5 \%(\alpha)(p=0.210 ; p>0.05)$. The reason for rejecting the fourth hypothesis is that most DPS at Islamic commercial banks in Indonesia have almost the same educational background. Of the 20 DPS people from 8 Syariah Commercial Banks in Indonesia, 13 DPS were graduated from doctoral program of sharia economy/banking/finance or around 65\%. 6 DPS people are graduated from sharia economy/banking and finance economics or about 30\%. And only 1 DPS is a graduate of Islamic economics/banking and finance or about $5 \%$.

Double positions in DPS have a significant negative effect on profit sharing financing. The results of this study are in accordance with the theory of Islamic Corporate Governance that links all concepts and behaviors in business governance with things that are transcendental and immanent. DPS that has fewer positions in general can increase community trust so as to increase financing for profit sharing.

Usamah's research (2010) concluded that multiple positions proved to have an effect on syariah-based financing of results-based compliance because it was seen from the significance probability for multiple positions at 0.002 at the level of $5 \%(\alpha)(p=0.002 ; p>0.05)$. Therefore, it can be concluded that the variable profit sharing is influenced by multiple positions. The smaller DPS members who hold concurrent positions, the higher BUS profit sharing financing.

\section{The Effect of Total DPS Monitoring Days on Revenue Sharing}

The sixth hypothesis (H6) states that the number of DPS supervision days has a positive effect on revenue sharing financing is rejected. This is not in line 
with the stewardship that management as a servant is not motivated by individual goals but rather is aimed at their primary outcome goals for the benefit of the organization (Davis et al., 1997). The results of the study show that the regression coefficient is 0.006 with a significance value of 0.255 . This shows that the number of DPS supervision days has no significant effect on profit sharing financing because the p-values are $\geq 0.050$. So that it can be concluded that the number of DPS supervision days has no significant effect on revenue sharing.

\section{The Effect of Profit Sharing Financing on Financial Performance of Syariah Commercial Banks}

The profit sharing fund does not affect the financial performance of Islamic Commercial Banks. This is not in line with Stewardship theory, Profit Sharing in accordance with syariah principles in the management of operations and business of Syariah banking can eliminate public doubts about syariah banking services so that it will affect their decision to choose or continue to use services provided by Syariah banks.

In accordance with the research from Khasanah and Yulianto (2015), the variable profit-sharing financing had a positive and insignificant effect on BUS financial health in Indonesia. This shows that the higher the value of financing for the results will not affect the financial performance of syariah commercial banks.

\section{The Effect of DPS Scientific Background on Financial Performance of Syariah Commercial Banks Through Profit Sharing}

Based on the Sobel test to test which states that the scientific background of the DPS partially has a positive effect on the financial performance of Syariah Commercial Banks through profit sharing financing the results are rejected. These results are not in line with the theory of Islamic Corporate Governance that links all concepts and behavior in business governance with things that are transcendental and immanent. DPS that have an educational background in sharia/banking/finance/economics graduates can generally 
improve the financial performance of syariah commercial banks through profit-sharing financing which also increases.

Profit sharing cannot be used as an intermediary to strengthen the JIAFR | 20 relationship between DPS scientific background and the financial performance of syariah commercial banks, these results can be supported by data showing that the average profit sharing financing is 0,3871 . It shows that the financing of profit sharing is low in accordance with the criteria/indicators that have been set.

\section{The Effect of DPS Position Multiple Against Financial Performance of Islamic Commercial Banks Through Profit Sharing}

The capture of DPS positions partially has a negative effect on the financial performance of Syariah Commercial Banks through profit sharing financing showing the results of being rejected. This means that the variable profit sharing financing has not been able to mediate the relationship between multiple DPS variable positions on the financial performance of Islamic Commercial Banks. These results are not in line with the theory of Islamic Corporate Governance that links all concepts and behavior in business governance with things that are transcendental and immanent.

Profit sharing cannot be used as an intermediary to strengthen the dual relationship of DPS positions on the financial performance of syariah commercial banks, these results can be supported by data showing that the average profit sharing financing is 0,3871 . It shows that the financing of profit sharing is low in accordance with the criteria/indicators that have been set.

\section{The Effect of DPS Control Days on Financial Performance of Syariah Commercial Banks Through Profit Sharing}

The tenth hypothesis states that the number of DPS supervision days has a positive effect on the financial performance of syariah commercial banks through profit sharing financing is rejected. This is not in line with the Islamic Corporate Governance theory that links all concepts and behavior in business governance with transcendental matters and immanent. 
Profit sharing financing cannot be used as an intermediary to strengthen the relationship between the number of DPS supervision days to the financial performance of syariah commercial banks, this result can be supported by data showing that the average profit sharing financing is 0,3871 . It shows that the financing of profit sharing is low in accordance with the criteria/indicators that have been set.

\section{Conclusion}

Based on the results of research and discussion it can be concluded that the variable number of days of DPS supervision partially has a positive effect on the financial performance of syariah banks, while the DPS scientific background, dual DPS positions, number of DPS supervision days and profit sharing financing have no effect. Double positions in DPS have a significant negative effect on revenue sharing, while the DPS scientific background and number of days of DPS supervision are not. Profit sharing financing is unable to mediate the relationship between DPS scientific background, dual DPS position and number of DPS supervision days on the financial performance of syariah commercial banks.

This research provides advice for Islamic Commercial Banks in Indonesia to improve the financial performance of Islamic Commercial Banks in accordance with syariah principles. The researchers further suggested developing a research model on the characteristics of the Syariah Supervisory Board on the Financial Performance of Syariah Commercial Banks by using other intervening variables.

\section{References}

Arifni, Umi. (2015). The Effect of Islamic Good Corporate Governance on Profit Sharing Financing through Sharia Compliance, Accounting Analysis Journal, 1-12.

Asrori. (2014). The Implementation of Islamic Corporate Governanceand Its Implication on Syariah bank Performance, Jurnal Dinamika Akuntansi,, 6(1), 90-102. 
Ratna Fitriana, Agung Yulianto, Badingatus Solikhah

Bukair, A. A., \& Rahman, A. (2015). The Effect of the Board of Directors' Characteristics on Corporate Social Responsibility Disclosure by Islamic Banks, Journal of Management Research, 7(2), 506-519.

Davis, J., Schoorman, F., \& Donaldson L. (1997). Toward a Stewardship JIAFR | 22 Theory of Management, Academy of Management Review, 22(1), 20-47.

Ghifari, M. A, Handoko, L. H., \& Yani, E. A. (2015). The Analysis Of Sharia Banking Performance In Indonesia and Malaysia Using The Index Maqashid Approach, Jurnal Ekonomi dan Perbankan Syariah, 3(2), 4766.

Hameed, S., Wirman, A., Alrazi, B., Nazli, M., \& Pramono, S. (2004). Alternative disclosure and performance measures for Islamic Banks, Second Conference on Administrative Sciences: Meeting the Challenges of the Globalization Age,King Fahd University of Petroleum \& Minerals, Dhahran, Saudi Arabia, 19-21. https://doi.org/10.1017/CB09781107415324.004.

Hawary, D. E., Grais, W., 7 Iqbal, Z. (2004). Regulating Islamic financial institutions: The nature of the regulated, World Bank Policy Research Working Paper, 1-49.

Hasanah, U. (2015), The Effect of Compliance with Sharia Principles and Islamic Corporate Governance on Financial Performance in Islamic Commercial Banks, Thesis. Semarang: Universitas Negeri Semarang.

Khasanah, Z., \& Yulianto, A. (2015). Islamic Corporate Governance and Islamic Social Reporting on The Syariah Comercial Bank, Accounting Analysis Journal, 6(4), 1-10.

Rama, A., \& Novela, Y. (2015). Sharia Governance and The Quality of Corporate Governance in The Islamic Banking, Signifikan, 4(2), 111126.

Rifai, A., \& Asrori. (2017). Analysis of Influence of Characteristics of Islamic Supervisory Board toward Islamic Financial Performance. Accounting Analysis Journal, 6(2), 277 - 287.

Sudaryati, D., \& Eskadewi, Y. (2012). The influence of Corporate Governance toward Corporate Social Reponsibility Disclosure in Syaria Banking, Jurnal Ekonomi dan Bisnis, 11(1), 14-28.

Suhendar, C. Y., \& Tanuatmodjo, H. (2014). The Effect of Sharing Profit on Profitability of Sharia Banks, Antologi Pendidikan Akuntansi dan Keuangan, 2(2), 1-6. 
Triyuwono, I. (2007). Mengangkat "Sing Liyan" untuk Formulasi Nilai tambah Syariah. Prosiding of Simposium Nasional Akuntansi X. Makasar: Indonesia.

Usamah. (2010), The Effect of Competence and Syariah Supervisory Board Orgnization Model on Profit Sharing financing in The Syariah banking in Indonesia, Thesis. Semarang: Universitas Diponegoro.

Yulianto, A., \& Solikhah, B. (2016). The Internal Factors of Indonesian Sharia Banking to Predict The Mudharabah Deposits, Review of Integrative Business and Economics Research, 5(1), 210-218.

Zaman, R. M., \& Movassaghi, H. (2002). Interest-Free Islamic Banking: Ideals and Reality, International Journal of Finance, 14, 2428-244. 
JIAFR | 24 